\title{
PROGRAM PENGEMBANGAN KEWIRAUSAHAAN (PPK) BERBASIS USAHA BUDIDAYA DAN TEKNOLOGI HASIL PETERNAKAN DI FAKULTAS PETERNAKAN UNIVERSITAS HALU OLEO
}

\author{
Ali Bain ${ }^{1}$, La Ode Arsad Sani ${ }^{2}$, La Ode Syukur ${ }^{3}$, Rusli Badaruddin ${ }^{4}$, La Ode Muh. Safaat ${ }^{5}$, \\ I Putu Nara Prasanjaya ${ }^{6}$ \\ 1,2,4,6 Fakultas Peternakan, Universitas Halu Oleo, Kendari \\ ${ }^{2}$ Fakultas Keguruan dan Ilmu Pendidikan, Universitas Halu Oleo, Kendari \\ ${ }^{3}$ Fakultas Pertanian, Perikanan dan Peternakan, Universitas Sebelas November \\ email alibain1967@yahoo.com
}

\begin{abstract}
ABSTRAK
Lulusan perguruan tinggi memiliki potensi yang besar untuk dipersiapkan menjadi wirausahawan yang unggul, yang tidak hanya akan memandirikan dirinya secara ekonomi kelak, tetapi juga akan turut mengembangkan potensi ekonomi daerah yang pada gilirannya akan berdampak positif bagi perekonomian negara. Program-program pengembangan kewirausahaan bagi mahasiswa dicanangkan oleh pemerintah, sehingga banyak mahasiswa memulai aktivitas usaha sejak masa perkuliahan. Hal ini juga terjadi bagi mahasiswa Fakultas Peternakan Universitas Halu Oleo, yang banyak berusaha dibidang peternakan. Beberapa jenis usaha mahasiswa Fakultas Peternakan antara lain usaha budidaya ternak terutama ternak unggas, usaha produksi hasil peternakan, dan usaha pengolahan limbah sisa hasil peternakan. Dalam menjalankan usaha, mahasiswa peternakan banyak menghadapi kendala diantaranya adalah sebagai berikut kurangnya keterampilan manajemen usaha dan manajemen keuangan, kurangnya pengetahuan tentang strategi pemasaran yang baik, kurangnya pengetahuan dalam pemanfaatan teknologi informasi, tidak adanya jejaring usaha dan kurangnya permodalan. Solusi yang tepat untuk mengatasi permasalahan yang dihadapi dalam kegiatan program pengembangan kewirausahaan (PPK) ini, adalah dengan melakukan pelatihan dan pembimbingan wirausaha. Program pengembangan kewirausahaan ini dilaksanakan selama 3 tahun. Pada tahun pertama kegiatan-kegiatan yang dilakukan dalam PPK ini adalah (a) pelatihan kewirausahaan dengan manteri diantaranya menitik beratkan pada manajemen produksi; (b) magang kewirausahaan di perusahaan yang sesuai dengan jenis usaha masing-masing; (c) busisness opportunity dengan perusahaan mitra; dan (d) pemberian bantuan dana bergulir. Tahun kedua kegiatan yang dilakukan sama dengan tahun pertama, namun dalam pelatihan kewirausahaan selain aspek produksi, juga lebih banyak pembahasan aspek pemasaran produk, aspek pembiayaan usaha, dan manajemen pembukuan usaha. Tahun ketiga, selain kegiatan yang dilaksanakan pada tahun pertama dan kedua, pada tahun ini juga kegiatan pelatihan dan pembimbingan diarahkan pada proses legalitas usaha dan upaya perluasan usaha. Kegiatan ini bertujuan untuk menciptakan mahasiswa berjiwa wirausaha yang kompeten di bidangnya sejak masa perkuliahan, serta meningkatkan keterampilan dan pengetahuan mahasiswa tentang prosedur menjalankan usaha yang baik. Hasil dari kegiatan ini diharapkan dapat tercipta minimal 5 wirausahaan baru setiap tahun, yang mampu menghasilkan produk secara mandiri. Selain itu, kegiatan ini juga dapat menghasilkan: (a) jurnal nasional terakreditasi pada Jurnal Ilmu dan Teknologi Peternakan Tropis (JITRO) setiap tahun; (b) artikel media cetak lokal pada Koran Kendari Pos dan publikasi media online pada OKESULTRA.COM setiap tahun; (c) artikel prosiding seminar nasional pada tahun kedua dan ketiga; (d) paten sederhana pada tahun ketuga; (e) Usulan merk dagang produk yang dijual pada tahun ke 3 kegiatan; (f) desain produk industri pada tahun ke dua; (g) Draf buku ber ISBN pada tahun ke 3 kegiatan.
\end{abstract}

Kata Kunci : Program Pengembangan Kewirausahaan, Fakultas Peternakan, Universitas Halu Oleo 


\begin{abstract}
University graduates have great potential to be prepared to become excellent entrepreneurs, who will not only establish themselves economically in the future, but will also contribute to developing regional economic potential which will in turn have a positive impact on the country's economy. Entrepreneurship development programs for students launched by the government, so many students start business activities since the lecture. This also happened to Halu Oleo University's Faculty of Animal Husbandry students, who had a lot of effort in the field of animal husbandry. Some types of business of the Faculty of Animal Husbandry include: livestock farming, especially poultry, livestock production, and livestock waste management. In running a business, animal husbandry students face many obstacles including the following: lack of business management and financial management skills. Lack of knowledge about good marketing strategies, lack of knowledge in utilizing information technology, lack of business networks and lack of capital. The right solution to overcome the problems encountered in the activities of the entrepreneurship development program (EDP), is to conduct training and mentoring entrepreneurship. This entrepreneurship development program was carried out for 3 years. In the first year the activities carried out in this KDP were as follows: (a) entrepreneurship training with a spell including focusing on production management; (b) entrepreneurship apprenticeships in companies that are appropriate to their respective types of business; (c) business opportunity with partner companies; and (d) providing revolving fund assistance. The second year the activities carried out the same as the first year, but in entrepreneurship training in addition to the production aspect, there was also more discussion of product marketing aspects, business financing aspects, and business bookkeeping management. The third year, in addition to the activities carried out in the first and second year, this year also the training and mentoring activities are directed at the business legality process and efforts to expand the business. This activity aims to create entrepreneurial students who are competent in their fields since the lecture period, and improve students' skills and knowledge about the procedures for running a good business. The results of this activity are expected to create at least 5 new entrepreneurs every year, who are able to produce products independently. In addition, this activity can also produce: (a) an accredited national journal in the Journal of Science and Technology of Tropical Animal Husbandry (JITRO) each year; (b) local print media articles in Kendari Pos Newspapers and online media publications on OKESULTRA.COM every year; (c) national seminar proceedings articles in the second and third years; (d) a simple patent in the current year; (e) Proposed trademarks of products sold in the 3rd year of activity; (f) industrial product design in the second year; (g) ISBN book draft in year 3 of activity.
\end{abstract}

Keywords: Entrepreneurship Development Program, Faculty of Animal Husbandry, Halu Oleo University

\title{
PENDAHULUAN
}

Perkembangan dunia kewirausahaan saat ini bagi generasi muda tidak terlepas dari peran pengembangan kewirausahaan di dunia pendidikan terutama pendidikan formal di kampus. Peningkatan peran perguruan tinggi dalam mempersiapkan wirausaha pada hakikatnya persiapan kader wirausaha adalah dalam segi penempaan karakter wirausaha. Mengingat masih tingginya tingkat pengangguran di kalangan terdidik, khususnya para alumni perguruan tinggi, mulai tahun 1997 Direktorat Pendidikan Tinggi Departemen Pendidikan Nasional terpanggil untuk aktif mengembangkan budaya kewirausahaan di perguruan tinggi dengan menyediakan anggaran dana untuk kegiatan pendukung kewirausahan seperti kuliah kewirausahaan (KWU), kuliah kerja nyata usaha (KKN-U), klinik konsultasi bisnis dan 
penempatan kerja (KBPK), magang kewirausahaan (MKU), program kreatifitas mahasiswa (PKM) dan inkubator wirausaha baru (INWUB). Pengalaman di berbagai negara maju menunjukkan bukti bahwa semakin banyak penduduk yang melakukan kegiatan ekonomi melalui wirausaha, akan berdampak pada kemajuan ekonomi bangsa tersebut.

Universitas Halu Oleo (UHO) telah melakukan banyak upaya dalam meningkatkan jiwa kewirausahaan di lingkup civitas akademika baik kepada dosen, staf, maupun kepada mahasiswa melalui berbagai pelatihan dan workshop yang bertemakan kewirausahaan. Peningkatan jiwa kewirausahaan mahasiswa Universitas Halu Oleo dapat tercermin pada pelaksanaan beberapa kegiatan oleh mahasiswa. Pertama, peningkatan jumlah mahasiswa yang lolos seleksi program kreativitas mahasiswa (PKM) diberbagai kategori selama 2 tahun terakhir, yakni 52 judul tahun 2017 dan 107 judul tahun 2018. Khusus PKMK, yakni 7 judul tahun 2017 dan 15 judul tahun 2018. Kedua, Universitas Halu Oleo setiap tahunnya menyelenggarakan program mahasiswa wirausaha (PMW), dimana pada tahun 2017 sebanyak 40 orang mahasiswa didanai dalam PMW dan tahun 2018 direncanakan sebanyak 60 orang mahasiswa didanai dalam progran wirausaha mahasiswa (PMW).

Keberhasilan penerapan jiwa kewirausahaan dalam lingkup Fakultas Peternakan UHO, dapat dilihat pada kurun waktu 5 tahun terakhir, sebanyak 12 judul proposal berhasil didanai oleh Program Kreativitas Mahasiswa dengan total mahasiswa yang terlibat sebanyak 36 orang. Sebanyak 10 judul dari 12 judul PKM adalah Program Kreativitas Mahasiswa Kewirausahaan (PKMK) dengan jenis usaha semuanya bergerak pada bidang peternakan. Hal ini menandakan bahwa besarnya peluang usaha bidang peternakan, mulai dari usaha produksi sampai pengolahan hasil. Mahasiswa Fakultas Peternakan UHO juga berhasil memperoleh dana dalam Program Kewirausahaan Mahasiswa (PMW), dimana sebanyak 17 judul proposal usaha dibidang peternakan mendapatkan bantuan modal dari program PMW.

Selain kedua program tersebut, Fakultas Peternakan juga meningkatkan minat mahasiswa dalam melakukan usaha melalui pemanfaatan fasilitas-fasilitas yang dimiliki fakultas. Mahasiswa diberi kesempatan untuk menempati kandang-kandang produksi peternakan melalui seleksi setiap tahunnya. Sebanyak 5 orang setiap angkatan diberi kesempatan untuk berwirausaha memelihara ternak baik ternak ayam broiler, ayam petelur, ayam kampung, puyuh, kambing dan ternak sapi. Produk-produk yang telah dihasilkan oleh para calon tenant adalah sebagai berikut antara lain: daging ayam broiler, daging ayam kampung, telur ayam ras, telur puyuh, bakso ayam, bakso sapi, telur asin, dan pupuk organik.

Meskipun demikian, dalam menjalankan usaha para calon tenant, masih banyak menghadapi kendala diantaranya adalah sebagai berikut: kurangnya keterampilan manajemen usaha dan manajemen 
keuangan, kurangnya pengetahuan tentang strategi pemasaran yang baik, kurangnya pengetahuan dalam pemanfaatan teknologi informasi, tidak adanya jejaring usaha dan kurangnya permodalan. Oleh karena

itu, diperlukan langkah yang tepat untuk mengatasi permasalahan tersebut. Kegiatan ini bertujuan untuk menciptakan mahasiswa berjiwa wirausaha yang kompeten di bidangnya sejak masa perkuliahan, serta meningkatkan keterampilan dan pengetahuan mahasiswa tentang prosedur menjalankan usaha yang baik khususnya usaha di sektor peternakan.

Berdasarkan uraian di atas maka PPK di Fakultas Peternakan Universitas Halu Oleo ini, difokuskan pada kegiatan kewirausahaan di bidang peternakan yang meliputi, usaha budidaya ternak ayam broiler, usaha ternak ayam kampung, usaha ternak puyuh, usaha produksi bakso dan telur asin, dan usaha pembuatan pupuk organik oleh mahasiswa FPt UHO. Berkaitan dengan bidang PPK yang diusulkan maka mahasiswa yang direkrut menjadi tenant adalah mahasiswa Fakultas Peternakan UHO yang telah mendapatkan/sedang melakukan kegiatan PKM/PKMK dan PMW, alumni, dan mahasiswa yang sedang merintis usaha sebanyak 20 orang.

\section{METODE}

\section{Rekrutmen Tenant Peserta PKK}

Dalam rangka melaksanakan program pengembangan kewirausahaan di Fakultas Peternakan UHO untuk menghasilkan 5 (lima) wirausahawan dalam kurun waktu satu tahun, pengelola melakukan rekruitmen tenant peserta PPK yang berasal dari mahasiswa program PKM/PKMK dan PMW yang sedang berjalan, mahasiswa alumni program PKM/PKMK dan PMW, alumni melalui jaringan alumni, dan mahasiswa di luar program PKM/PKMK dan PMW. Dalam pola rekruitment ini dilakukan dengan cara memberikan kesempatan bagi setiap mahasiswa atau tenant yang sedang atau sudah merintis kegiatan usaha di luar kelompok alumni, dan di luar program PKMK, artinya berasal dari mahasiswa Fakultas Peternakan baik yang sudah atau belum mengambil mata kuliah kewirausahaan yang berminat dan intens dengan kegiatan kewirausahaan.

Pada tahun pertama PPK (Tahun 2019), akan direkrut mahasiswa tenant sebanyak 20 orang. Peserta tenant tersebut terdiri dari mahasiswa Fakulta Peternakan UHO yang memiliki rintisan usaha dibidang peternakan sesuai program yang direncanakan. Setelah pelaksanaan PPK tahun pertama selesai diharapkan sedikitnya 25-30\% (5-7 orang) dari total tenant telah dapat mandiri menjalankan usahanya sendiri dan dapat membantu teman peserta PPK lainnya untuk mempersiapkan usaha baru pada tahun 
berikutnya. Dalam mempersiapkan perekrutan tenant baru pada tahun-tahun berikutnya akan dilakukan pembinaan kepada mahasiswa yang belum menjadi tenant dengan cara mengarahkan/menganjurkan mahasiswa semester 4 ke atas Fakultas Peternakan di UHO untuk membuat proposal kegiatan PKMK dan PMW pada Tahun 2019, berkaitan dengan pengembangan manajemen usaha dalam program PPK. Upaya tersebut dimaksudkan agar dalam kegiatan pembinaan kelompok unit usaha mahasiswa di PPK pada tahun berikutnya tetap memenuhi kuota 20 tenant.

\section{Pendekatan Metode Pelaksanaan}

Tahun pertama metode pendekatan yang digunakan dalam rangka program pengembangan kewirausahaan di Fakultas Peternakan UHO dilakukan dengan beberapa tahapan antara lain :

1) Inventarisasi usaha calon tenant. Dalam rangka mencari dan mewadahi calon tenant maka perlu dilakukan inventarisasi terkait usaha calon tenant. Proses seleksi ini dilakukan dengan cara membuat standarisasi terkait calon tenant yang sedang merintis atau sudah melaksanakan kegiatan usaha. Penilaian dan seleksi didasarkan atas studi kelayakan usaha dari calon tenant. Dengan cara ini maka akan didapatkan calon tenant yang berkualitas mengingat banyaknya calon tenant yang berminat dan memiliki jenis bidang usaha yang beragam.

2) Bimbingan kewirausahaan. Kegiatan bimbingan usaha dilakukan oleh tim pengelola program pengembangan kewirausahaan bersama dengan perusahaan mitra dengan model pendidikan dan pelatihan dengan mengambil tempat di perusahaan mitra ataupun di Fakultas Peternakan UHO. Pola yang dilakukan adalah dengan model ceramah, workshop, dan diskusi materi sesuai dengan kompetensi bidang yang dimiliki oleh para tentor baik dari tim pelaksana maupun perusahaan mitra dan pihak perbankan. Tabel 1. Tema materi pelatihan tahun pertama.

3) Magang kewirausahaan di perusahaan mitra. Penyaluran kegiatan magang dilakukan berdasarkan jenis usaha para tenant dengan disesuaikan ruang lingkup perusahaan mitra. Secara kompetensi bidang usaha perusahaan mitra akan disesuaikan dengan jenis dan bidang usaha para tenant dalam program PPK.

4) Business opportunity dengan perusahaan mitra. Dalam kegiatan business opportunity ini para tenant melakukan kegiatan usaha secara rill dengan melakukan kolaborasi dengan perusahaan mitra, bilamana jenis usaha tenant yang sesuai dengan perusahaan mitra dapat melakukan kerjasama sebagai pemasok atau penyedia bahan bagi perusahaan mitra (kegiatan hulu dan hilir) atau menjadi mitra dalam pendistribusian produk dari tenant atau sebaliknya. 
5) Bantuan dana pembelian peralatan dan perbaikan sarana produksi. Dalam pelaksanaan PPK, disiapkan bantuan dana bergulir yang dapat digunakan dalam pembelian peralatan dan perbaikan sarana produksi. Bantuan dana pertama akan diberikan kepada 10 orang tenant yang dipilih berdasarkan atas studi kelayakan usaha dari calon tenant. Jumlah dana yang disiapkan Rp. 6.000.000,- untuk setiap tenant. Pemberian dana ini diberikan dengan skema pengembalian 4 kali selama 2 tahun. Dana hasil pengembalian akan diberikan kepada tenant yang lain yang belum mendapatkan dana bergulir. Pemberian dana bergulir ini direncanakan berjalan terus menerus, bahkan setelah program PPK berakhir ditahun ke-3.

6) Monitoring dan evaluasi tenant. Monitoring dan evaluasi dilakukan dengan melihat dari berbagai aspek baik dari aspek sosial, produksi, pemasaran, keuangan dan sebagainya. Program monitoring ini dilakukan dengan cara mewajibkan tenant membuat laporan. Selama proses pelaksanaan kewirausahaan mahasiswa tenant akan selalu dipantau oleh tim pelaksana PPK. Selepas kegiatan pelatihan materi secara teoritis dan praktikum, setiap minggu tim pelaksana PPK mengunjungi lokasi-lokasi wirausaha tenant guna memantau dan mengawasi serta sekaligus memberikan konsultasi kepada mahasiswa tenant yang berkaitan dengan kegiatan kewirausahaannya.

\section{Lembaga lain yang terlibat sebagai Mitra}

Pelaksanaan Program Pengembangan Kewirausahaan (PPK) ini juga didukung oleh beberapa lembaga dan perusahaan sebagai mitra, yakni:

a. PT. Jass Mandiri Sejahtera Unit Kendari, yaitu perusahaan yang bergerak dibidang kemitraan unggas.

b. PT. Senayan Group yaitu perusahaan yang menaungi beberapa rumah makan di Kota Kendari diantaranya RM Bakso Senayan, RM Bakso Indonesia dan RM Wong Jowo. Selain itu perusahaan ini juga mempunyai usaha peternakan puyuh.

\section{PEMBAHASAN}

\section{Pelatihan Program Pengembangan Kewirausahaan}

Suatu usaha yang ada perlu dikembangkan untuk memperoleh hasil yang maksimal melalui pelatihan kewirausahaan. Selain untuk meningkatkan pengetahuan wirausaha peserta, pelatihan ini juga dapat membangun keterampilan produksi. Kegiatan ini menghadirkan pemateri yang ahli dibidangnya, 
sehingga materi yang diterima peserta lebih terbarukan dan dapat dipahami dengan mudah. Kegiatan yang dijadikan usaha beragam namun pelaksanaan workshop yang terkhusus untuk makan terbatas. Pelaksanaan pelatihan pengembangan program usaha yang diterapkan melalui beberapa tahap yaitu workshop, praktek, kunjuangan pada industri UMKM dan magang di industri terdekat utamanya yang memiliki kaitan dengan usaha yang akan dijalankan.

Menurut Shodikin dkk. (2018), program pengembangan kewirausahaan memberikan perbaikan dalam pengelolaan tenant, menghasilkan produk berbasis IPTEK dan terbentuknya jasa dan kerjasama dengan pihak-pihak terkait. Namun perlu diperhatikann terkait aspek pendukung dan penghambat kewirausahaan seperti kecemasan, semangat dan kesiapan tenant.
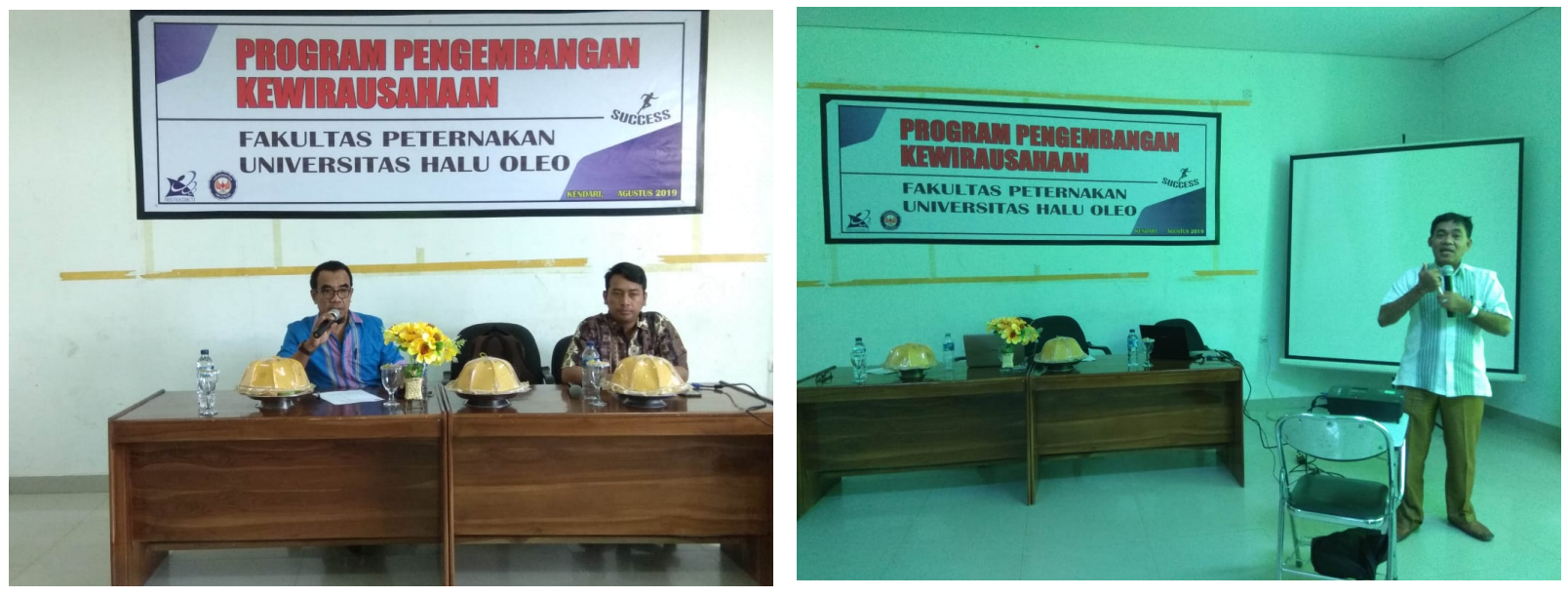

Gambar 1. Pelatihan Program Pengembangan Kewirausahaan

\section{Program Usaha Telur Tersadis}

Program usaha Telur Tersadis adalah sebuah program usaha yang bertujuan untuk membuat olahan telur menjadi telur asin. Telur merupakan produk peternakan yang cukup populer dikalangan masyarakat di seluruh Indonesia, memiliki harga yang murah, sehingga dapat dijangkau oleh seluruh lapisan masyarakat. Telur asin adalah sebuah olah yang berasal dari telur yang dibuat untuk memberikan keberagaman rasa pada telur yang biasa dikonsumsi setiap hari. Bahan utama pembuatan telur asin biasanya berasal dari telur itik dengan menambahkan garam sebagai pemberi rasa (Flavour) utama. Adonan yang biasa dibuat untuk menyimpan telur adalah abu dan sekam halus dari penggilingan beras.

Minat masyarakat untuk mengonsumsi telur asin cukup tinggi, karena telur ini memiliki rasa khas yang tidak dimiliki oleh produk lain. Maka dari itu, pembuatan dan pengembangan usaha Telur Tersadis akan memberikan keuntungan yang cukup tinggi. Telur asin yang telah dihasilkan selanjutnya 
akan dipasarkan baik penawaran secara konvensional (offline) maupun melalui media online (Facebook, WhatsApp, IG dll), sehingga penjualan dapat menjangkau pasar lebih luas.

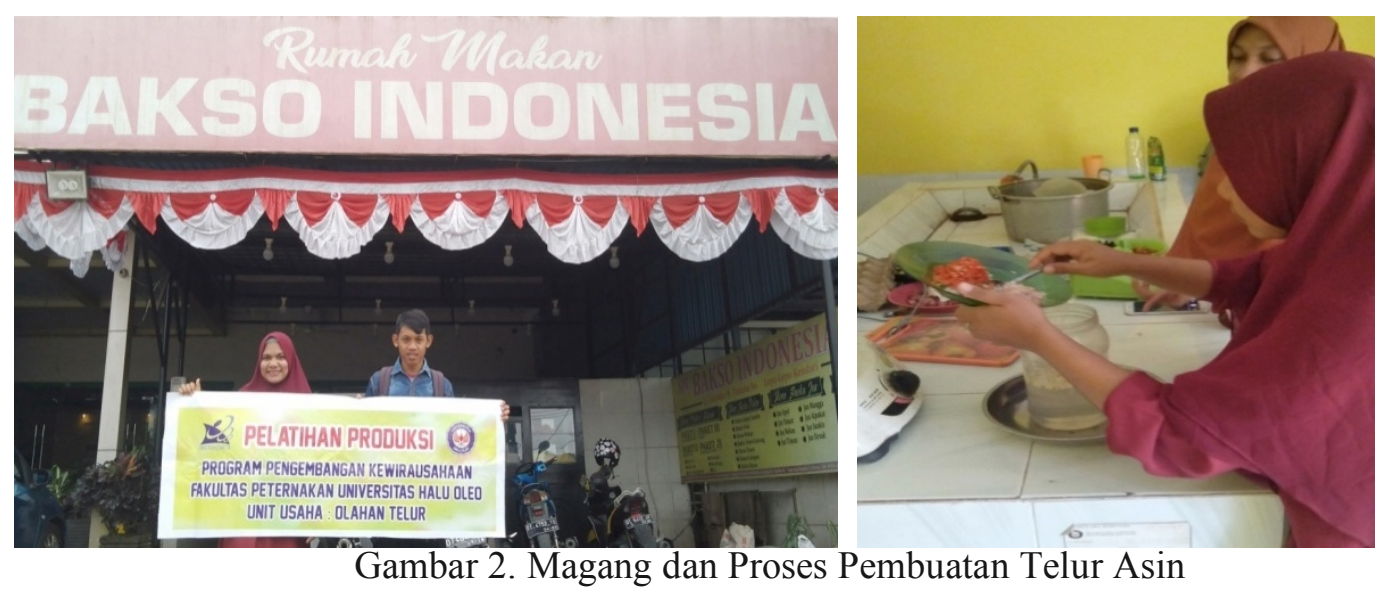

Objek pasar yang dituju untuk pemasaran produk ini tidak dibatasi usia, anak-anak, remaja bahkan orang tua dapat menikmati produk telur asin. Hal ini dikarenakan telur asin tidak memberikan dampak atau bahaya bagi konsumen, tidak mengandung bahan pengawet sintetik tapi menggunakan pengawet alami dari garam sehingga aman untuk dikonsumsi meskipun ada beberapa pertimbangan untuk konsumen tertentu. Selain itu, dengan pemberian garam sebagai bahan pengasinan, selain mempengaruhi karakter fisik, kimia maupun organoleptik dari telur asin, juga mempengaruhi nilai gizinya (Munir dan Wati, 2014).

\section{Program Usaha Budidaya Ayam Broiler}

Usaha budidaya ayam broiler adalah jenis usaha yang dinilai dapat memberikan keuntungan yang cukup baik saat ini. Jika ditinjau dari permintaan konsumen akan daging ayam, ayam broiler menempati peringkat minat terbanyak. Sehingga tidak heran jika banyak usaha-usaha yang didirikan untuk budidaya dan memproduksi ayam broiler. Usaha yang ada saat ini masih belum mampu untuk memenuhi permintaan konsumen akan daging ayam. Maka dari itu, diperlukan pengembangan usaha untuk menghasilkan produksi lebih optimal. 

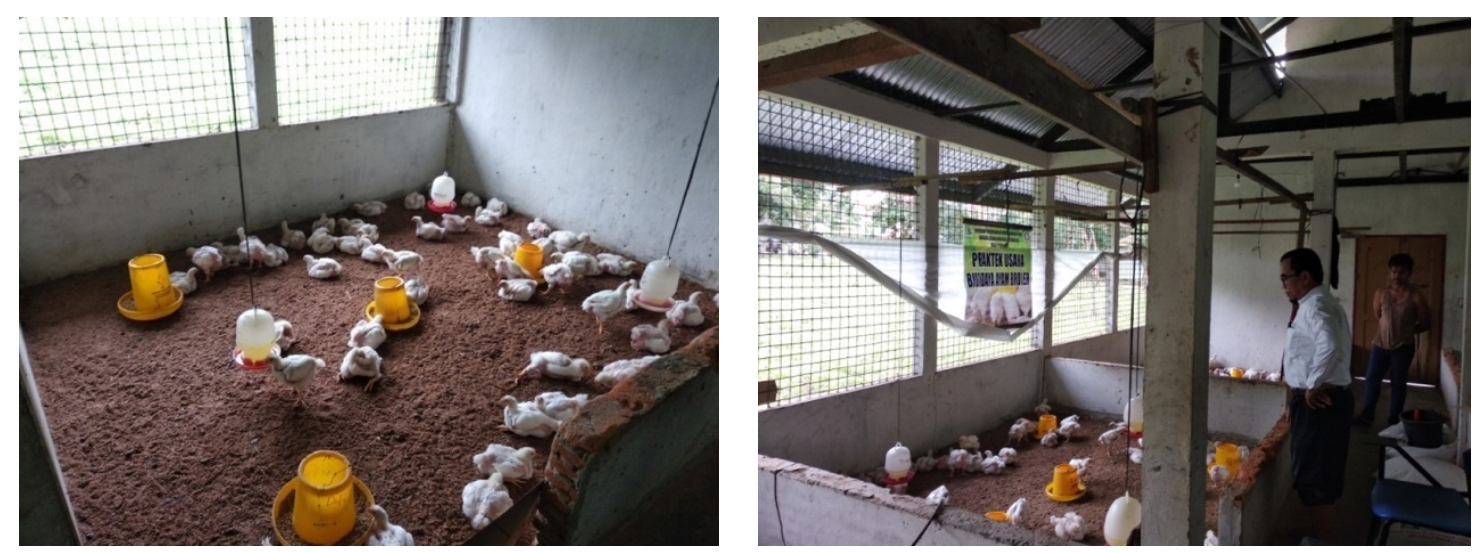

Gambar 3. Kondisi Kandang 1 Budidaya Ayam Broiler
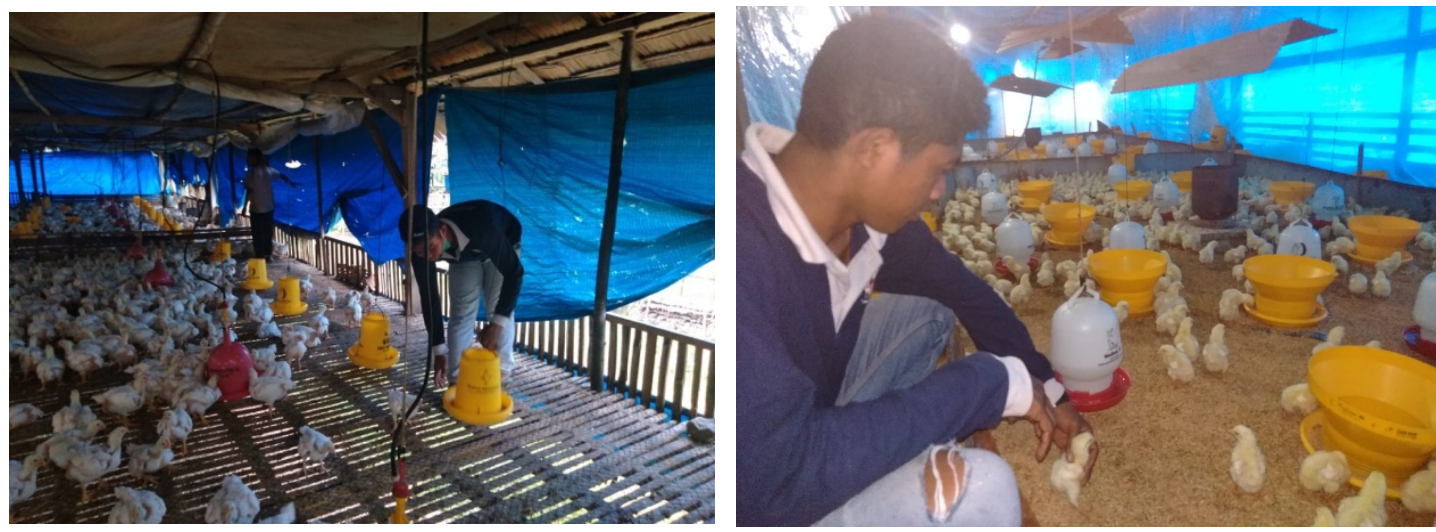

Gambar 4. Kondisi Kandang 2 Budidaya Ayam Broiler

Ayam broiler memiliki masa produksi cukup singkat yaitu sekitar 21-45 hari telah menghasilkan produksi yang maksimal. Hal ini terjadi karena ayam broiler didukung oleh sifat genetik dan keadaan lingkungan yang meliputi makanan, temperatur lingkungan dan pemeliharaan yang lebih intensif (Umam dkk., 2014). Dengan masa produksi yang cukup singkat ini, ayam broiler dapat dipanen beberapa kali dalam setahun. Selain itu, daging ayam yang dihasilkan cukup baik, tidak alot, sehingga dapat dinikmati oleh seluruh lapisan masyarakat termasuk orang tua usia lanjut.

Pemasaran hasil produksi dilakukan dengan cara pemasaran konvensional secara langsung kepada konsumen dan pemasaran menggunakan media online (Facebook, WhatsApp, IG dll). Pemasaran konvensional dilakukan dengan memasarkan produk ke pasar-pasar terdekat dari lokasi produksi seperti pasar sentral yang ada di kota Kendari. Selain ke pasar, produk yang dihasilkan juga ditawarkan kepada dosen tenaga pengajar dan mahasiswa yang ada di Universitas Halu Oleo pada 
umumnya dan Fakultas Peternakan khususnya. Harga produk disesuaikan dengan harga ayam broiler yang berlaku di pasaran pada umumnya, sehingga tingkat harga penjualan tidak dikhawatirkan oleh konsumen. Untuk mempermudah konsumen dalam melakukan pembelian dilakukan sebuah cara dengan memberikan tarif pengantaran nol rupiah untuk pemesanan secara online yang berada di lokasi tidak jauh dari area produksi.

\section{Program Usaha Ayam Kampung Super}

Upaya untuk memaksimalkan kebutuhan protein dan permintaan daging yang semakin tinggi perlu dikembangkan untuk meningkatkan produksi ternak sebagai penghasil daging ayam kampung yaitu ayam kampung super (Wiranata dkk., 2017). Usaha ayam kampung super merupakan usaha yang bertujuan untuk menghasilkan ayam kampung dengan pemeliharaan lebih singkat jika dibandingkan dengan ayam kampung pada umumnya. Ayam kampung super dapat dipanen pada umur 3 bulan sedangkan ayam kampung biasa hanya dapat dipanen pada umur 6 bulan, padahal permintaan dan harga ayam kampung cukup tinggi di pasaran. Menurut Kaleka (2015), ayam kampung super memiliki keunggulan diantaranya adalah dapat diproduksi dengan jumlah yang banyak dengan bobot yang seragam, tingkat pertumbuhan lebih cepat jika dibandingkan dengan ayam kampung biasa, memiliki tingkat mortalitas yang rendah serta memiliki rasa yang gurih. Maka dari itu, pengembangan usaha ayam kampung super akan memenuhi permintaan konsumen akan ayam kampung dua kali lipat lebih cepat jika dibandingkan ayam kampung biasa.

Ayam kampung super merupakan hasil silangan antara ayam bangkok yang memiliki pertumbuhan yang cepat dengan ayam petelur untuk menghasilkan anakan DOC yang cukup tinggi. Karena ayam kampung super berasal dari persilangan dua ayam tersebut, ayam ini tidak meninggalkan rasa khas ayam kampung pada umumnya. Rasa inilah yang biasanya diburu oleh konsumen, apalagi rasa khasnya tidak dimiliki oleh ayam broiler. Ayam kampung yang dijual di pasaran memiliki jumlah yang sedikit jika dibandingkan dengan ayam broiler. Sehingga ayam ini memiliki harga yang cukup tinggi.

Singkatnya pemeliharaan dan harga yang tinggi, menjadikan usaha ini akan memberikan keuntungan yang cukup tinggi apabila dikembangkan dengan baik apalagi dengan metode pemasaran yang cukup mudah. Biasanya hanya dengan melakukan penawaran secara konvensional saja ayam ini 
bisa terjual habis. Namun untuk memperoleh lingkup pasar yang luas, penjualan ayam kampung super juga merambah pada pemasaran melalui media online (Facebook, WhatsApp, IG dll).
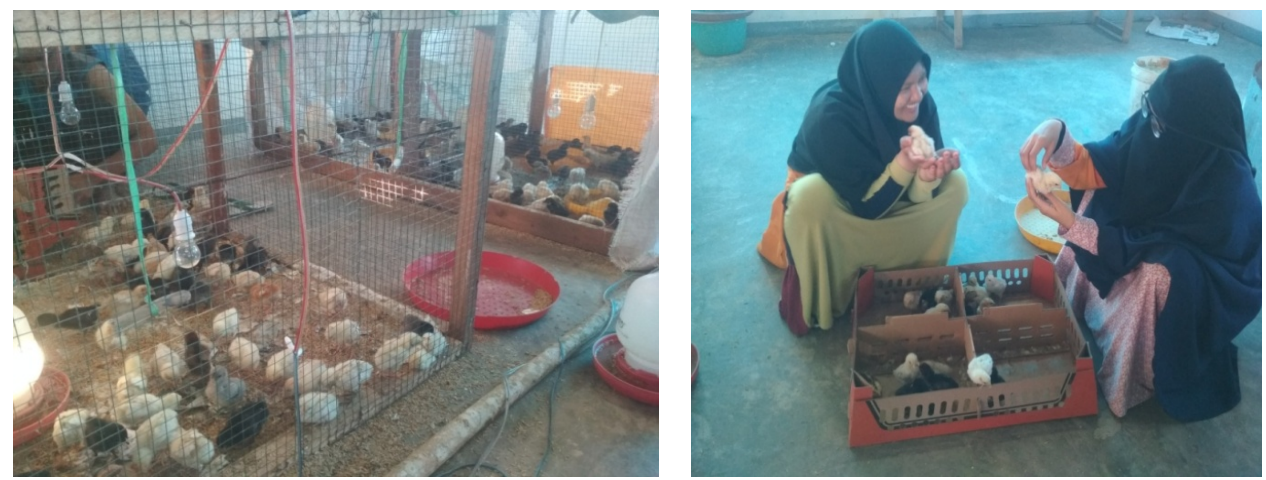

Gambar 5. Pemeliharaan Ayam Kampung Super

\section{Program Usaha Ternak Puyuh}

Puyuh adalah ternak unggas kecil yang memiliki potensi untuk dikembangkan sebagai suatu usaha. Selain menghasilkan telur, ternak ini juga memiliki bentuk yang lucu dan unik. Telur puyuh memiliki kandungan protein yang cukup tinggi jika dibandingkan dengan ayam petelur. Kandungan protein dan kolesterol dalam telur puyuh sangat baik untuk menunjang pertumbuhan bagi anak-anak. Dengan bentuk yang kecil telur ini akan menarik perhatian bagi konsumen utamanya anak-anak. Dalam prospek pengembangan usaha puyuh petelur masih memiliki berbagai macam kendala bagi peternak yang masih baru. Namun jika peternak telah menguasai seluk beluk burung puyuh tentu akan lebih mudah diatasi permasalahannya (Hartono, 2004). Mahasiswa FPt UHO memiliki cukup kualifikasi untuk meningkatkan kemajuan usaha puyuh petelur agar menjadi lebih baik.
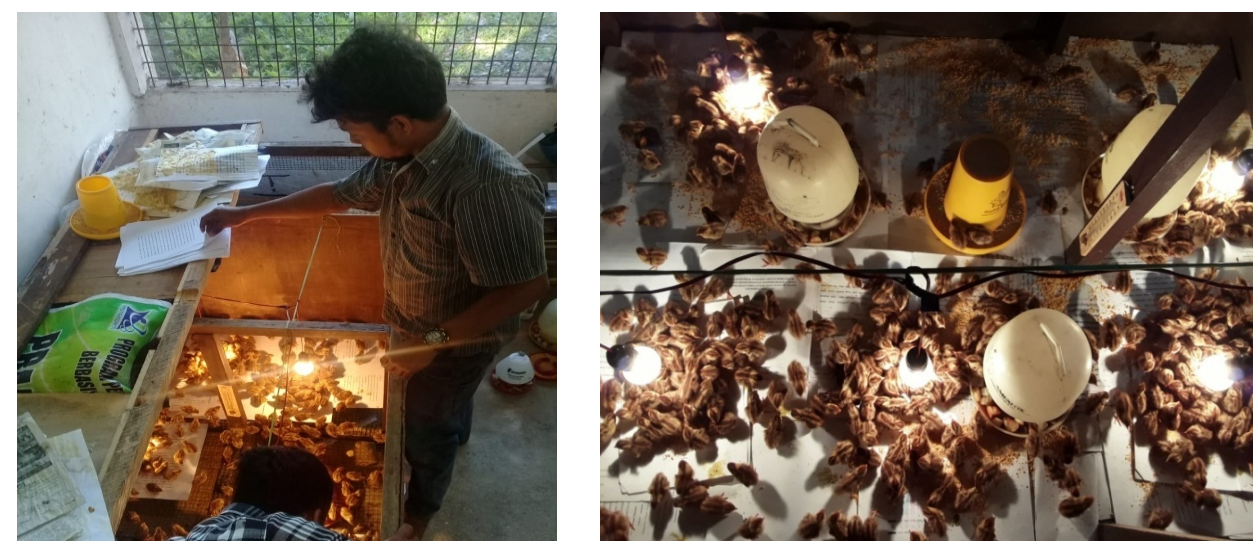

Gambar 6. DOQ dan Proses Pemeliharaannya 
Pemeliharaan burung puyuh cukup mudah dan tidak memerlukan lokasi yang luas jika dibandingkan dengan ayam petelur. Sehingga pengembangan usaha jenis ini memungkinkan untuk dijadikan usaha yang menjanjikan. Pemasaran telur burung puyuh hampir sama dengan pemasaran telur pada umunya namun dengan harga yang lebih murah. Satu butir telur puyuh hanya dikenakan harga Rp. 500, dan per raknya sekitar Rp. 45.000. harga yang cukup terjangkau dan jumlah yang lebih banyak. Telur puyuh selain dikonsumsi langsung juga dapat dijadikan isian beberapa makanan dan jajanan lain. Pemasaran bisa dilakukan melalui mitra, konvensional dan pemasaran melalui media online.

\section{Program Usaha Bakso}

Bakso merupakan produk olahan daging giling yang dicampur dengan tepung dan bumbu serta bahan lain yang dihaluskan, kemudian dibentuk bulatan-bulatan dan kemudian direbus hingga matang (Astawan, 2008). Bakso adalah salah satu makanan olahan yang berasal dari daging sapi atau ayam berbentuk bulat dan biasa disajikan dalam bentuk kuah bersama campuran lainnya dan bentuk bakar. Makanan olahan ini sangat banyak diburu oleh konsumen utamanya para penikmat kuliner. Bakso banyak dijumpai di berbagai warung makan karena rasanya yang khas sangat berbeda dengan olahan lain. Pengembangan sebuah usaha pembuatan bakso akan memberikan dampak positif bagi produsen. Karena bakso memiliki permintaan yang cukup tinggi baik dari kalangan anak-anak, remaja bahkan orang tua.

Pembuatan bakso dengan menggunakan kap sebagai tempat penyajiannya dapat memberikan nilai tambah bagi konsumen dan produsen. Selain dapat mempermudah konsumen untuk menikmati hasil olahan, metode ini juga dapat mempermudah produsen karena mampu menarik perhatian konsumen untuk membelinya. Dengan adanya penggunaan kap sebagai tempat bakso konsumen dapat menikmati bakso dimana saja dan kapan saja tanpa khawatir akan terjadi kontaminasi dari luar.

Bakso yang dibuat dipasarkan baik secara konvensional maupun melalui media online seperti Facebook, WhatsApp, Instagram dll. Untuk mempermudah konsumen untuk menjangkau pembelian tanpa mengeluarkan biaya, pemberian tarif gratis pengantaran area produksi merupakan langkah tepat untuk dilakukan apalagi cara ini mampu untuk mempertahankan konsumen. 

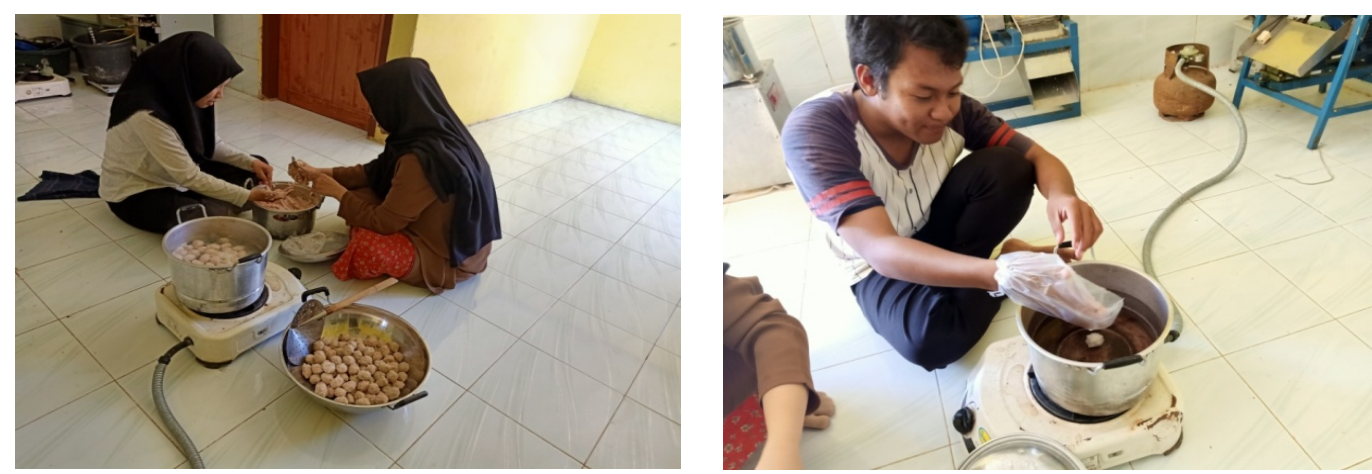

Gambar 7. Proses Pembuatan Bakso

\section{Program Usaha Pupuk Organik}

Permentan No.2/pert/Hk.060/2/2006, dikemukakan bahwa pupuk organik adalah pupuk yang berasal dari tanaman dan atau hewan terdiri atas bahan organik yang telah melalui proses rekayasa, dapat berbentuk padat atau cair yang digunakan mensuplai bahan organik untuk memperbaiki sifat fisik, kimia dan biologi tanah (Juarsah, 2014). Usaha pupuk organik merupakan salah satu tindakan tepat untuk dilakukan saat ini, apalagi untuk mendukung salah satu program pemerintah yaitu go organik pada tahun 2010 silam. Selama ini masyarakat petani menggunakan pupuk kimia untuk memicu pertumbuhan tanaman pertanian. Salah satu alasan penggunaan pupuk kimia oleh petani adalah pupuk kimia mengandung unsur nutrien yang cukup banyak dan tidak membutuhkan kapasitas penggunaan yang banyak untuk memperoleh hasil yang maksimal. Tanpa disadari, penggunaan pupuk kimia memberikan dampak buruk baik bagi keseimbangan ekosistem lingkungan. Mengonsumsi makanan yang terkontaminasi dengan pupuk kimia dapat meninggalkan residu di dalam tubuh konsumen yang nantinya akan menimbulkan berbagai macam penyakit. Maka atas kesadaran inilah saat ini penggunaan pupuk kimia mulai dialihkan pada pupuk organik.
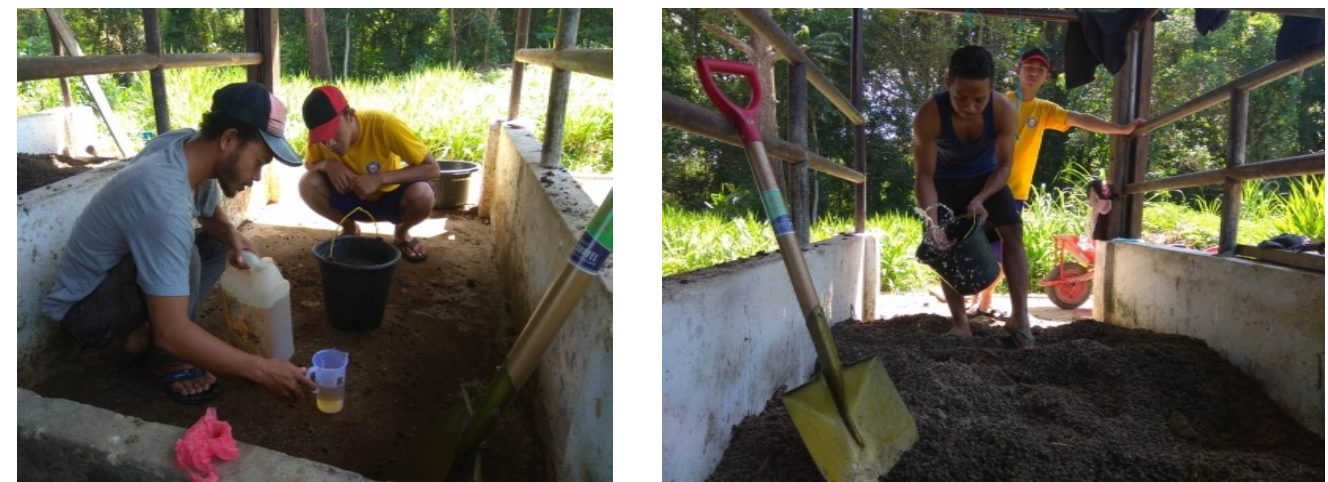

Gambar 8. Pembuatan Pupuk Organik 
Pupuk organik sangat baik untuk digunakan untuk memenuhi kebutuhan unsur hara tanaman pertanian, namun memerlukan penggunaan yang cukup banyak dalam satuan luasan lahan yang sama jika dibandingkan dengan pupuk anorganik (Purnomo dkk., 2013). Hal ini dikarenakan kandungan unsur hara yang sedikit namun lebih lengkap jika dibandingkan dengan pupuk kimia. Karena membutuhkan penggunaan yang banyak, pupuk ini harus diproduksi lebih banyak untuk memenuhi permintaan konsumen utamanya petani tanaman pangan.

Pengembangan usaha pembuatan pupuk organik adalah salah satu jenis usaha yang akan memberikan keuntungan yang cukup besar, apalagi jika ditinjau dari segi pemasaran sangat mudah untuk didistribusikan. Pembuatan dengan pengemasan yang baik akan memberikan daya tarik tersendiri dalam pemasarannya. Sehingga konsumen lebih tertarik untuk membeli pupuk organik. Pupuk organik berasal dari kotoran ternak sapi yang tidak diolah dicampur dengan beberapa bahan tambahan alami lainnya untuk menghasilkan pupuk organik berkualitas.

\section{SIMPULAN}

Program Pengembangan Kewirausahaan dengan pendekatan Participatory Action Learning System (PALS) terbukti memberikan perbaikan dalam pengelolaan tenant. Tiga fase yang dijalankan yakni penyadaran kewirausahaan (awareness), pengkapasitasan dan pendampingan kewirausahaan (entrepreneurship capacity building), dan pelembagaan (institutionalization) mampu meningkatkan motivasi dan pemahaman konsep kewirausahaan, meningkatkan kemampuan dalam manajemen, marketing usaha, serta kemampuan membuat produk dan kemasannya.

Pelaksanaan program pengembangan kewirausahaan ini merupakan program yang berkesinambungan dan tidak dapat selesai dalam satu periode. Pengawasan harus tetap dilakukan meskipun program sudah selesai. Program pengembangan kewirausahaan ini pelaksanaannya dapat diduplikasi sebagai referensi pendidikan kewirausahaan di tingkat perguruan tinggi.

\section{DAFTAR PUSTAKA}

Astawan, M. 2008. Sehat dengan Hidangan Hewani. Penebar Swadaya: Jakarta.

Hartono,T. 2004 Permasalahan Burung Puyuh dan Solusi. Penebar Swadaya: Jakarta.

Juarsah, I. 2014. Pemanfaatan Pupuk Organik untuk Petanian Organik dan Lingkungan Berkelanjutan. Prosiding Seminar Nasional Pertanian Organik . Balai Penelitian Tanah. Bogor.:127-136. 
Kaleka, N. 2015. Panen Ayam Kampung Super. Arcita:Solo.

Munir, I. M. dan Wati R.S. 2014. Uji Organoleptik Telur Asin dengan Konsentrasi Garam dan Masa Peram yang Berbeda. Seminar Nasional Teknologi Peternakan dan Veteriner 2014. Malang : 646649.

Purnomo, R., Mudji S. dan Suwasono H. 2013. Pengaruh Berbagai Macam Pupuk Organik dan Anorganik Terhadap Pertumbuhan dan Hasil Tanam Mentimun (Cucumis Sativus L). Jurnal Produksi Tanaman. Vol. 1(3) : 93-100.

Rhenald Kasali, dkk, 2010, Modul Kewirausahaan untuk program Strata 1, PT. Mizan Republika. Jakarta.

Shodikin, A. wahyu K.S. Sutardi dan Ali M. 2018. Program Pengembangan Kewirausahaan dan Alumni Universitas Islam Darul Ulum Lamongan. JPM (Jurnal Pemberdayaan Masyarakat. Vol. 3(2): 258-263.

Umam, M.K., Heni S.P. dan V.M. Ani N. 2014. Penampilan Produksi Ayam Pedaging yang Dipelihara pada Sistem Lantai Kandang Panggung dan Kandang Bertingkat. Jurnal Ilmu-Ilmu Peternakan. Vol. 24(3) : 79-87.

Wiranata, M.A., Joko I.S. dan Hariadi S. 2017. Analisis Profitabilitas Usaha Peternakan Ayam Kampung Super di Kabupaten Jember. Jurnal Ilmu Peternakan Terapan. Vol. 1(1) : 31-38. 